\title{
Working part-time in the British, German and Dutch labour market: scarring for the wage career?
}

Citation for published version (APA):

Fouarge, D., \& Muffels, R. (2009). Working part-time in the British, German and Dutch labour market: scarring for the wage career? Schmollers Jahrbuch: Journal of Applied Social Science Studies, 129(2), 217-226. https://doi.org/10.3790/SCHM.129.2.217

Document status and date:

Published: 01/01/2009

DOI:

10.3790/SCHM.129.2.217

Document Version:

Publisher's PDF, also known as Version of record

\section{Please check the document version of this publication:}

- A submitted manuscript is the version of the article upon submission and before peer-review. There can be important differences between the submitted version and the official published version of record.

People interested in the research are advised to contact the author for the final version of the publication, or visit the DOI to the publisher's website.

- The final author version and the galley proof are versions of the publication after peer review.

- The final published version features the final layout of the paper including the volume, issue and page numbers.

Link to publication

\footnotetext{
General rights rights.

- You may freely distribute the URL identifying the publication in the public portal. please follow below link for the End User Agreement:

www.umlib.nl/taverne-license

Take down policy

If you believe that this document breaches copyright please contact us at:

repository@maastrichtuniversity.nl

providing details and we will investigate your claim.
}

Copyright and moral rights for the publications made accessible in the public portal are retained by the authors and/or other copyright owners and it is a condition of accessing publications that users recognise and abide by the legal requirements associated with these

- Users may download and print one copy of any publication from the public portal for the purpose of private study or research.

- You may not further distribute the material or use it for any profit-making activity or commercial gain

If the publication is distributed under the terms of Article $25 \mathrm{fa}$ of the Dutch Copyright Act, indicated by the "Taverne" license above, 


\section{Working Part-Time in \\ the British, German and Dutch Labour Market:} Scarring for the Wage Career?

By Didier Fouarge and Ruud Muffels*

\section{Abstract}

The paper studies the long-term effect of part-time employment on the wage career using panel data for three countries. The main idea is to study the possible 'scarring' effects of part-time employment on future hourly wages up to ten years later in the career. Fixed effects panel wage regressions show the existence of a part-time wage penalty for females in all three countries and for males in the UK. Longer durations of part-time result in stronger negative wage effects. In the UK, a negative effect of past part-time employment is also found to persist even after a lasting transition to a fulltime job. The fact that the effect of part-time on wage is larger in the UK suggests that wage penalties, contrary to what could be expected, are smaller in regulated labour markets with a specific skills regime.

$J E L$ Classifications: $J 31, J 62, J 22, J 24$

\section{Introduction}

We use three long-running national panel studies for the Netherlands, the UK and Germany to investigate the long-term effects (ten years) of part-time employment on males" and females' wage careers. The existence of a parttime pay penalty is well established in the literature though most studies rely on cross-sectional data, are single-country studies or focuses on the short-term effects only (Gregory/Jukes, 2001; Russo/ Hassink, 2008; Bardasi / Gornick, 2008). We suspect part-time work to have long-term 'scarring' effects on the wage career either because of a lower human capital that is built up during the years of part-time work in the career or because it is a 'second best' option yielding a lower pay-off than a full-time job (Arulampalam, 2001; Gregory, 2001; Burgess, 2003; Paull, 2006). The issue is relevant since part-time employment is becoming an increasingly common phenomenon in Europe.

* The research was carried out in the framework of a project sponsored by the European Foundation for Living and Working Conditions in Dublin. We gratefully acknowledge their invaluable support and contribution to the project (see Muffels et al., 2008). 
The focus of the paper is twofold. 'Firstly, we examine the impact of parttime employment and its duration on the wage later in the career. Secondly, we investigate to what extent the wage penalty of past part-time employment remains significant after people have moved into a full-time job. Using panel data methodology, we find significant negative effects of part-time duration on the wage. However, the effects are larger in the UK than in Germany or the Netherlands. In the UK, this negative effect of part-time employment persists for both males and females, even after a lasting transition into full-time employment.

The paper is structured as follows. In Section 2 we discuss the research questions and hypotheses to be tested. In Section 3, we briefly discuss the data and the main variables used in the analyses. Section 4 provides some descriptive results on wages, while Section 5 presents and discusses the wage regressions. The main conclusions from the paper are summarized in Section 6 .

\section{Background and Research Questions}

The gender divide in labour market participation in Western economies has received much attention in the both the sociological (Fagan/Rubery, 1996) and economic literature (Euwals, 2001). Part-time employment has been shown to be a form of employment that allows for combining work and caring obligations, especially for female workers (Paull, 2008). However, part-time employment can be expected to have negative effects on earnings (Dekker et al., 2000; Ermisch / Wright, 1993). From a human capital perspective, this can be understood because part-time workers invest less in formal training and informal learning (Nelen/de Grip, 2009), and because they have a lower accumulation of experience over their life course (Hirsch, 2005). ${ }^{2}$

The research questions to be tackled read as follows:

1. To what extent does part-time employment in the past have a 'scarring' effect on the current wage level? More precisely, what is the impact of a history of part-time employment on the current wage? If part-time employment is indeed 'scarring', one would expect that wage earners with parttime employment experience end up with lower wages, even after returning to full-time employment.

2. Which differences are to be found across the three welfare states in the socalled 'scarring' effects of past part-time employment on the wage career?

1 In the full version of this paper, we also investigated the 'scarring effects' of parttime work on employment one, three and five years later in the career (Fouarge / Muf-

2 The difference in training investments between part-time and full-time workers is
fels, 2006). due to firms' human resources practices.
Which role is played by the labour market itself vis a vis the hourly wage offered in part-time jobs, the type of 'skills regime' or the supporting institutions?

\section{Hypotheses}

Workers who work part-time, e.g. due to caring duties, incur a loss of human capital accumulation and are more likely to get a lower paid job. This is more likely to be the case as the spell of part-time employment is longer. It is also more likely that they return to a lower paid job in a labour market that rewards firm-specific skills more than general human capital such as in the regulated labour markets of the Netherlands and Germany. According to the Varieties of Capitalism literature in these countries pay systems are linked to internal labour markets, and skills acquired on the job are relatively more rewarded than formal skills acquired through general education (Hall/Soskice, 2001). This brings us to formulate the following three hypotheses:

Hypothesis 1: The hourly wage level is likely to be lower for males as well as for females having worked part-time in the past ten years.

Hypothesis 2: The scarring effect of part-time work history on the current wage level also exists for women who worked part-time ten years earlier but moved into a full time job for the last five years.

Hypothesis 3: The negative effect of part-time employment on future earnings, is likely to be stronger in regulated labour markets with a specific skills regime such as in the Netherlands and Germany than in the unregulated labour markets with a general skills regime such as in the UK.

\section{Data, Methodology and Main Definitions}

Data

In this paper, we use the long running panel data for the Netherlands (SEP $1984-2002$ ), the UK (BHPS, 1991-2003) and Germany (SOEP, $1994-$ 2006). These are the three longest running panel data in Europe. The sample is restricted to people aged 16-64 years not being self-employed (we exclude the self-employed because they do not face the same constraints when deciding on their working hours). The descriptive analyses are weighted.

\section{Variables}

Considering a moving time-windows of 10 years, we measure whether or not respondents are currently working part-time (less than 35 hours), were working part-time over this period, and the total number of years that he/ she

Schmollers Jahrbuch $129(2009) 2$ 
worked part-time. In order to focus on the wage effects of part-time employment, workers with career interruptions are removed from the data. The dependent variable is the log of the gross hourly wage rate. In the SOEP and SEP, we use gross yearly earnings for the year prior to the survey year. Gross yearly earnings have been divided by the number of hours worked on a yearly basis in the corresponding year. All wage data are expressed in Euros in constant 2005 prices. The covariates included in the model are duration of past part-time employment, a dummy for current part-time employment, gender, educational level, occupational level, number of children, household type, sector of industry, wage level in $t-10$, year dummies, and for Germany, a dummy for East Germans.

$$
\text { Methods }
$$

The strategy to answer the research questions is twofold. Firstly, we present and discuss descriptive statistics on the extent of part-time employment in the three countries under study, the duration of part-time employment, and the hourly wages for different employment patterns. Secondly, we estimated OLS wage regressions and GLS panel wage regressions to estimate the effect of part-time employment and its duration on hourly wages for males and females separately.

\section{Descriptive Results}

trastas.

The share of part-time work has been increasing in the Netherlands and Germany between 1984 and $2001 / 2006$ but only for females, whereas the share remains rather stable in the UK for both men and women between 1991 and 2003. However, the share of part-time work is larger in the Netherlands, especially for women $(73 \%$ in 2001$)$ but also for men (18\%) compared to Germany (47\% and $8 \%$ in 2006) and the UK (41\% and $6 \%$ in 2003). While durations of part-time employment are more or less similar in the UK and Germany (5.1 years for females, and 2.1 and 2.5 for UK and German males respectively), Dutch male and female workers remain on average longer in parttime ( 3.9 and 6.6 years respectively).

Table 1 shows the gross hourly wage of employed males and females in the Netherlands, the UK and Germany at ten year time intervals in the course of their careers. We present a breakdown according to the current state of parttime employment, as well as the past history of part-time employment. That is, we take the traditional full-time career as the point of reference (always fulltime), and we compare the hourly wages of workers who were not employed full-time during the past ten years. They either worked full-time now and ten years later but worked part-time occasionally in the years in between, they worked part-time at $t=1$ but full-time ten years later, or they worked parttime at $t=1$ and part-time ten years later:
Table 1

Hourly wage according to current number of hours worked and past part-time history, $t 1$ and $t 10$

\begin{tabular}{|c|c|c|c|c|c|c|}
\hline \multirow{2}{*}{ The Nethertands } & \multicolumn{3}{|c|}{ Males } & \multicolumn{3}{|c|}{ Females } \\
\hline & wage $t$ & wage $t 10$ & growth & wage $t 1$ & $\mid$ wage $t 10 \mid$ & growth \\
\hline Allways full time & 16.3 & 19.6 & $21 \%$ & 13.3 & 16.8 & $27 \%$ \\
\hline Full time $t \& \& t 10$, some part-time & 15.9 & 19.9 & $25 \%$ & 12.3 & 16.1 & $31 \%$ \\
\hline Part-time $t: \&$ full-time $t 10$ & 16.2 & 16.8 & $3 \%$ & 12.8 & 14.8 & $15 \%$ \\
\hline Part-time $t 1$ \& part-time $t 10$ & 18.7 & 22.3 & $20 \%$ & 13.5 & 15.0 & $11 \%$ \\
\hline Total & 16.3 & 19.5 & $19 \%$ & 13.3 & 15.3 & $15 \%$ \\
\hline \multirow{2}{*}{ UK } & \multicolumn{3}{|c|}{ Males } & \multicolumn{3}{|c|}{ Females } \\
\hline & wage $t 1$ & wage $t 10$ & growth & wage $t 1$ & wage $t 10$ & growth \\
\hline Allways full time & 8.4 & 11.2 & $34 \%$ & 6.8 & 9.6 & $42 \%$ \\
\hline Full time $t 1 \& t 10$, some part-time & 7.0 & 9.0 & $29 \%$ & 6.3 & 9.3 & $47 \%$ \\
\hline Part-time $t 1$ \& full-time $t 10$ & 11.2 & 10.0 & $-11 \%$ & 6.2 & 7.5 & $20 \%$ \\
\hline Part-time $f$ \& part-time $t 10$ & 21.4 & 9.9 & $-54 \%$ & 5.7 & 6.9 & $20 \%$ \\
\hline Total & 8.5 & 11.1 & $31 \%$ & 6.3 & 8.1 & $30 \%$ \\
\hline \multirow{2}{*}{ Germany } & \multicolumn{3}{|c|}{ Males } & \multicolumn{3}{|c|}{ Females } \\
\hline & wage $t 1$ & wage $t 10$ & growth & wage $t 1$ & wage 110 & growth \\
\hline Allways full time & 17.2 & 20.5 & $19 \%$ & 13.3 & 16.1 & $21 \%$ \\
\hline Full time $t 1 \& t 10$, some part-time & 18.4 & 21.2 & $15 \%$ & 13.6 & 16.6 & $22 \%$ \\
\hline Part-time $t /$ \& full-time $t 10$ & 32.0 & 20.3 & $-37 \%$ & 15.0 & 13.9 & $-8 \%$ \\
\hline Part-time $t 1$ \& part-time $t 10$ & 21.2 & 23.0 & $8 \%$ & 12.3 & 13.8 & $12 \%$ \\
\hline Total & 17.9 & 20.6 & $15 \%$ & 13.2 & 14.9 & $13 \%$ \\
\hline
\end{tabular}

Sotrce: SEP, SOEP, BHPS.

The table shows that overall, male and female full-time workers saw their hourly wages rise more than workers of the same gender with a part-time work history. It also shows that females working part-time generally earn less than females in full-time jobs. For males, this is not always the case. The reason for this is that males, when they work full-time, work on average more hours (than full-time working females), which reduces their hourly wage accordingly.

\section{Explaining the Evolution of Hourly Wages over Time}

We have estimated two models for examining the impact of part-time work history on the evolution of the current hourly wage level.

Sclmollers Jahrbuch $129(2009) 2$ 
- In Model I we relate the current hourly wage to the part-time employment history in the past ten years (number of times worked part-time in the last ten years), the wage level ten years earlier, and the control variables listed in Section $3^{3}$

- In Model II we restrict the sample to people who worked in a full-time job for at least the past five years, and model the effect of having worked in a part-time job in the years prior to those five years. This allows us to examine the impact of a history of part-time employment on the current wage for people who made a lasting re-entry in full-time employment.

The models were estimated for males and females separately. We employed OLS, and random and fixed effects GLS wage regression models to correct for unobserved heterogeneity. The OLS estimates might be biased due to time constant but unobserved or latent individual (heterogeneity) effects such as personality traits (ability, effort or motivation). If the individual effects are uncorrelated with one or more of the observables (such as the past wage or the current and past part-time work history to which our main interest goes) the random effects model is appropriate whereas when they are correlated with these observables the fixed effects model should be preferred. Table 2 reports the findings for the OLS, the random and fixed effects GLS models according to Model I and Model II for the Netherlands, Germany and the UK. In Model II we leave out the OLS results because the Breusch-Pagan LM test shows that the GLS random effects specification should be preferred.

The main conclusions to be drawn from the models for the Netherlands are that there is a sizeable negative effect of part-time work history on the current hourly wage for both sexes in the OLS and the random effects specification (Model I). This effect, however, becomes insignificant for males in the fixed effects specification. For Dutch females, the effect is negative and significant: the more years they have worked in a part-time job in the last ten years the lower their wage level. After having worked for at least five years in fulltime employment (Model II) there is still a negative effect of part-time work experience for males, but remarkably so not for females anymore in the random effects model. The gross hourly wage for males is reduced by some $1.7 \%$ per year of part-time employment. In the fixed effects model, however, the penalty for males on hourly wages as well as for females has turned insignificant. Note, however, that for most females in the Netherlands working full-

3 The coefficients for the control variables included in the model and the variance components are not reported in Table 2 . They are available upon request from the authors.

4 The Hausman specification test indeed suggests that in all three countries the fixed effects models should be preferred

$s$ The different results in the fixed effects model compared to the random model suggest that part-time experience could be correlated to unobserved individual characteristics. time is not the standard employment pattern. This implies that our results might be based on a selective group of employed females who, due to a higher human capital or stronger preferences, are better equipped to move into a fulltime career. Even though we correct for unobserved heterogeneity in the random and fixed effects models the estimates might still be biased when the individual effects do not capture the selectivity appropriately. If they however do, the results suggest that part-time jobs in the Netherlands are not too 'bad' compared to full-time jobs especially for females.

For Germany the effect of part-time employment history on the current wage level is negative in Model $I$ for males and females in the random effects model. In the fixed effects specification, we only find a significant negative effect for females. However, even after having worked five years in full-time employment (Model II), there is still a sizeable negative effect of part-time work history on the wage level for males and females $(-3.2 \%$ and $-1.9 \%)$. The negative effects on wage in the fixed effects model are small and insignificant in Germany. Furthermore, the wage levels in Eastern-Germany are $14 \%$ (for females) to $30 \%$ (for males) below the wage levels in the Western part even after part-timers have moved into a stable job.

In the UK, the adverse wage effect of having worked part-time in the past ten years is even stronger than for Dutch and German females $(-3.7 \%)$. Males who have worked part-time in the past also appear to have a significantly lower wage $(-5.5 \%)$. This suggests that male part-time jobs are rather marginal jobs. When males working part-time do return to a full time job for the five consecutive years, they have to cope with a significantly lower wage level (Model II). This also holds for females, although according to the fixed effects specification this effect is about half the size compared to that of males. The findings therefore confirm the existence in the UK of a sizeable scarring effect of part-time work history on the wage level, even after their return into full time employment. A possible explanation is given by "occupational segregation' or part-time jobs being relatively 'bad' jobs in terms of pay and promotion chances in the UK (see also Manning/ Petrongolo, 2008).

\section{Conclusion}

The results confirm our first and second hypotheses that there is a scarring effect of part-time work history in the last ten years on the current wage. For those who make a lasting transition to full-time employment, we do not observe a scar effect in Germany or the Netherlands. But full-time workers with a history of part-time employment earn significantly less in the UK. This is not in line with our third hypothesis derived from the Varieties of Capitalism literature. According to that hypothesis part-timers incur larger wage losses in specific skills regimes, making it less likely that they return to full time jobs. 


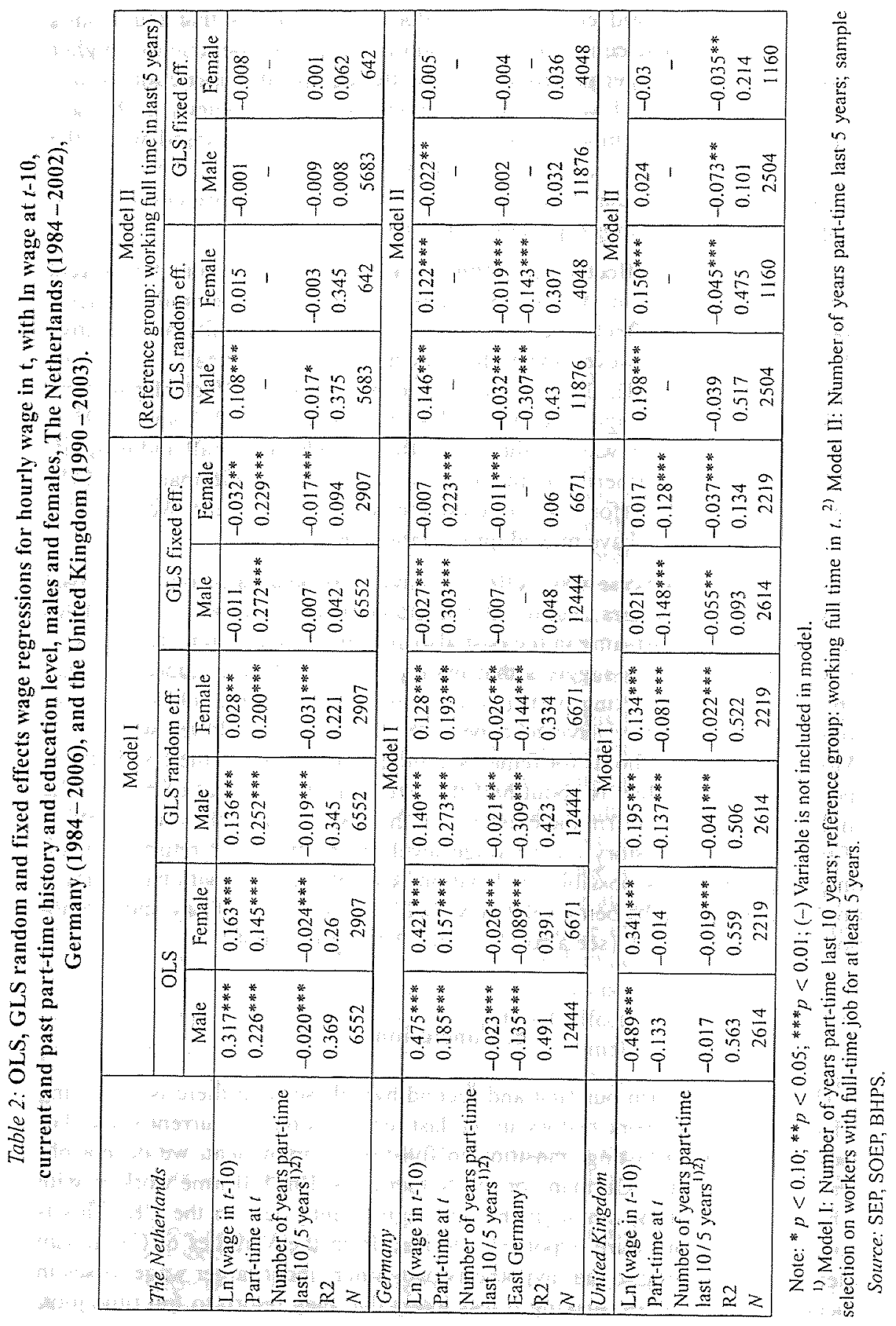

Sclimollers Jahrbuch $129(2009) 2$
The reason for our finding might be that the Netherlands and Germany offer better institutional support to working mothers (income support and active labour market policies) or that there are stronger preferences for working parttime in these countries. However, we find evidence that part-time jobs in the Netherlands and Germany are 'not too bad' jobs compared to full-time jobs in the sense that wages are not far below that of full-time jobs. This might also be related to strong social support in society for especially working mothers to be engaged in part-time jobs. The lack of income and employment support to working mothers in the UK might explain the long time it takes for British women to recover from the wage penalty they confront. Even after five years in full-time employment they are not able to recover fully from the wage penalty. We find evidence that due to occupational segregation part-time jobs in the unregulated UK seem to be of rather low quality offering rather low wages compared to full-time jobs, and poor wage career chances. Again, the lack of institutional and social support for part-time work in the UK might be responsible for part-time jobs to be of lower quality offering lower wages and therefore attracting people with lower skills.

In future research apart from finding better ways to correct for the selectivity into full-time jobs we might add more countries for deriving more robust evidence on the institutional differences observed here. We also would like to add more detail on education level and training to be able to measure changes in human capital in a better way. Eventually, we would like to add more information on working time preferences and on labour market opportunities to distinguish between choice and constraints in a better way.

\section{References}

Bardasi, E./ Gornick, J. C. (2008): Working for less? Women's part-time wage penalties across countries, Feminist Economics 14 (1), 37-72.

Dekker, R./Muffels, R. J. A./ Stancanelli, E. (2000): A longitudinal analysis of parttime work by women and men in the Netherlands, in: Gustafson, S. S. / Meulders, D. (eds.), Gender and the labour market: Econometric evidence of obstacles to achieving gender equality, New York, 260-287.

Etwals, R. (2001): Female Labour Supply, Flexibility of Working Hours, and Job Mobility, The Economic Journal 111 (471), 120-134

Fagan, C./Rubery, J. (1996): The Salience of the Part-Time Divide in the European Union, European Sociological Review 12 (3), $227-250$.

Fouarge, D./ Muffels, R. (2006): Working part-time and caring in Europe: short and medium-term effects on the career and income, mimeo, Tilburg University.

Gregory, M./Jukes, R. (2001): Unemployment and subsequent earnings: Estimating scarring among British men $1984-94$, Economic Journal 111 (475), 607-625.

Schmollers Jahrbuch 129 (2009) 2 
Hirsch, B. (2005): Why do Part-Time Workers Earn Less? The Role of Worker and Job Skills, Industrial and Labor Relations Review 58 (4), 252-551.

Kalmijn, M.I Van Der Lippe, T. (1997): Type of Schooling and Sex Differences in Earnings in the Netherlands, European Sociological Review 13 (1), $1-15$.

Manning, A./Petrongolo, B. (2008): The part-time pay penalty for women in Britain, Economic Journal $118(526), 28-51$

Muffels, R./Chung, H./Fouarge, D./Klammer; U./Luijkx, R./Manzoni, A./Thiel, A./ Wilfitagen, T. (2008): Flexibility and Security over the Lifecourse, Luxembourg: Office for Offcicial Publications of the European Communities,

ISBN 978-92-897-0806-7, 51

Nelen, A. / de Grip, D. (2009): Why do Part-Time Workers Invest Less in Human Capital than Full-Timers?, LABOUR $23(1), 61-83$.

Paull, G. (2006): The impact of children on women's paid work, Fiscal Studies 27 (4), $473-512$.

Patll, G. (2008): Children and women's hours of work, The Economic Journal 118 , F8 - F27.

Russo, G./Hassink, W. (2008): The part-time wage gap: A career perspective Economist-Netherlands $156(2), 145-174$.

Uunk. W./ Kalmijn, M./ Muffels, R. (2005): The Impact of Young Children on Women's Labour Supply: A Reassessment of Institutional Effects in Europe, Acta sociologica $48,41-62$

\section{Older Babies - More Active Mothers? \\ How Maternal Labor Supply Changes}

as the Child Grows

By Katrin Sommerfeld*

\section{Abstract}

Female labor market activity is dependent on the presence and the age of a child, but how do the determinants develop in magnitude and significance with the child's age? Using German SOEP data from 1991 to 2006 for mothers with young children, the change in maternal labor supply when the child is one, two, and three years old is explicitly addressed. According to the tobit regression results for precise working hours, maternal labor supply becomes increasingly responsive to economic incentives - mainly to imputed wages - as the child grows

JEL-Classification: J13, J22, D13

\section{Introduction}

The current debate about maternity leave policies in Germany centers around the topic of maternal labor supply. Based on the aim of fostering fertility and the child's well-being, it is intended to facilitate the work-life balance of mothers. As the question of mothers' (re)entry into the labor market naturally comprises the timing of (re)entry, it is of great relevance to consider the development of maternal labor supply as the child grows. Thus it is of interest what determines if mothers return to the labor market and how much they work? Most of all: do these factors change with the age of the baby? For example, do mothers always respond to higher wages?

* I would like to thank the Center for European Economic Research (ZEW) in Mannheim where part of this research was conducted. In particular I am grateful to $S$. Steffes and B. Fitzenberger for helpful remarks. Moreover I thank participants at the 23rd Annual Congress of the European Economic Association in Milan, the 8th International German Socio-Economic Panel User Conference 2008 in Berlin, the XXII Amnual Conference of the European Society for Population Economics 2008 in London, and seminar participants at the Albert-Ludwigs-University Freiburg. All remaining errors are my own.

Schmollers Jahrbuch $129(2009) 2$ 
